\title{
JAUNŲ ŽMONIUৃ GYVENIMO KOKYBĖS IR RIEBIOS VEIDO ODOS SĄSAJOS
}

\author{
Gražina Šniepienė, Justina Gudaitytė, Simona Urbonienė \\ Klaipédos valstybinès kolegijos Sveikatos mokslu fakultetas
}

Raktažodžiai: riebi oda, gyvenimo kokybè, sebumas.

\begin{abstract}
Santrauka
Tyrimo objektas. Riebios veido odos poveikis gyvenimo kokybei. Tyrimo tikslas. Išanalizuoti jaunų žmonių gyvenimo kokybę ir riebios veido odos sąsajas. Tyrimo medžiaga ir metodai. Atliekant tyrimą taikytas originalus klausimynas, grịstas mokslo informacijos šaltiniais. Apklausti 396 18-35 metų amžiaus respondentai, iš kurių 128 turintys riebią veido odą. Duomenys analizuoti naudojant IMB SPSS Statistics (version 19) programinès ịrangos duomenų paketą. Analizuotiems duomenims buvo naudojami: Šapiro Vilko (Shapiro-Wilk), Kolmogorovo-Smirnovo (Kolmagorov-Smirnov) ir Kruskalio Voliso (Kruskal-Wallis) neparametriniai kriterijai, duomenys buvo koduojami, skaičiuojami vidurkiai, standartiniai nuokrypiai, mediana, dažniai, procentai, statistinis reikšmingumas.

Tyrimo rezultatai. Atlikus tyrimą nustatyta, kad riebią veido odą turintys jauni žmonès patiria socialinę ir emocinę atskirtį. Jie labiau vengia bendrauti su kitais žmonèmis, vengia viešų susibūrimų, dèl savo odos yra linkę būti namuose, jaučia stresą ir kitus nemalonius jausmus. Analizuojant surinktus duomenis pagal amžiaus grupes nustatyta, kad 18-23 metu amžiaus respondentai labiau jaučia riebios veido odos įtaką socialinei bei emocinei būsenai.

Išvados. Atlikus tyrimą paaiškejjo, kad riebi veido oda sukelia psichologinį diskomfortą ir turi įtakos jaunų žmonių gyvenimo kokybei. Nustatyta, kad riebi veido oda blogina ją turinčių žmonių socialinę ir emocinę būseną.
\end{abstract}

\section{İvadas}

Riebi oda paprastai apibūdinama kaip veido odos tipas, kuriam būdingos išsipletusios poros, riebumas ir blizgumas dèl per didelès odos riebalų sekrecijos. Šis odos tipas sukelia ne tik estetinį diskomfortą, tačiau gali būti ir tokių veido odos problemų, kaip aknè bei seborèjinis dermatitas, priežastimi $[5,11]$. Nors riebi veido oda laikoma santykinai normalia odos būkle, ji gali lemti žmogaus neigiamą savęs suvokimą, žemą savivertę, depresiją bei sielvartą, kurie gali turèti įtakos gyvenimo kokybei [3]. Vertinant jau atliktus tyrimus nustatyta, kad aknè berrimai yra paplitęs uždegiminis riebios odos susirgimas, kuris būdingas net 90 proc. paauglių, iš kurių pusei bèrimai arba liekamieji reiškiniai (randai, pigmentacija) tęsiasi ir suaugusiems (1 iš 3 tai pasireiškia ir sulaukus 40 metų amžiaus), o tai turi įtakos jų gyvenimo kokybei $[4,8]$.

Vertinant žmonių gyvenimo kokybę ir jos sąsajas su odos problemomis ypač dažnai naudojami tokie klausimynai kaip: DLQI (Dermatology Life quality Index), OSSIQ (Oily skin self image questionnary). Klausimynais nustatoma, kaip veido odos būklè per pastarajị laikotarpi veikė apklaustujjų gyvenimo kokybę $[7,13]$.

2017 metais atliktame tyrime ịrodyta, kad žmonès, turintys problemišką odą, turi socialinių, psichologinių ir emocinių sutrikimų, panašių i tuos, kurie serga sunkiomis ligomis $[1,10,16]$. Tiegiama, kad žmonès, turintys tokią odą, jaučiasi negražūs, jaučia diskomfortą bei yra susierzinę dèl tokios odos būklès [1,14].

Tyrimo tikslas: išanalizuoti jaunų žmonių gyvenimo kokybès ir riebios veido odos sąsajas.

\section{Darbo objektas ir metodika}

Tyrimo imtis ir atranka. Tyrimo imtis apskaičiuota remiantis Lietuvos statistikos departamento duomenimis, atrenkant 20-35 m. amžiaus Klaipėdos mieto gyventojus.

Tyrimui buvo pateikta anoniminė anketa internetu, socialiniuose tinkluose. Buvo taikoma kriterinè respondentų atranka. Anketinę apklausą iš viso užpilde 396 18-35 metų amžiaus respondentai, tačiau tyrimui buvo atrinkti 128 respondentai pagal kriterijus: turi riebią veido odą, gyvena Klaipedos mieste.

Analizuojant literatūrą nustatyta, kad riebalinių liaukų dydis ir aktyvumas yra didžiausias 18 - 35 metų žmonėms. O Pasaulinès Sveikatos Organizacijos (PSO) duomenimis, žmogus laikomas jaunu iki 44 metų. Todèl tyrimui buvo 
ieškoma jauno amžiaus (18 - 35 metų) respondentų, kurie vẻliau suskirstyti į tris amžiaus grupes: $18-23$ metų, $24-29$ ir $30-35$ metų.

Duomenų rinkimo metodai. Tyrimo duomenims surinti buvo vykdyta apklausa internete, taikant uždaro tipo klausimyną. Klausimynas pasirinktas, kad būtų ịvertintas respondentų odos tipas ir išsiaiškinta, kokią ittaką riebi veido oda turi jaunų žmonių gyvenimo kokybei. Klausimyną sudaro 25 uždaro tipo klausimai.

Duomenų analizès metodai. Tyrimo duomenims apdoroti buvo naudojamas IMB SPSS Statistics (version 19) programinès įrangos duomenu paketas. Duomenys buvo koduojami, standartizuojamos reikšmès, skaičiuojami vidurkiai, standartiniai nuokrypiai, mediana, dažniai, procentai, statistinis reikšmingumas. Pirmiausia buvo patikrinta, ar duomenys yra pasiskirstę pagal normalų skirstinị. Sprendžiant apie duomenų normalumą buvo naudojamas Šapiro Vilko kriterijus. Remiantis Šapiro Vilko kriterijų p reikšmėmis nustačius, kad duomenys nèra pasiskirstę pagal normalųji skirstinį, buvo naudojami neparametriniai kriterijai. Esant vienai respondentu grupei naudotas Kolmogorovo Smirnovo neparametrinis kriterijus, o esant daugiau nei dviem respondentų grupėms, skirtumams tarp jų vertinti buvo naudojamas neparametrinis ranginis Kruskalio Voliso kriterijus nepriklausomoms imtims.

\section{Rezultatai}

Vertinant jaunų žmonių, turinčių riebią odą, socialinę būseną naudotas Kolmogorovo Smirnovo neparametrinis kriterijus (1 lentelè).

Atlikus tyrimą nustatyta, kad visi respondentai patikimai įvertino visus socialinès būsenos elementus $(\mathrm{p}<0,001)$. Iš pateiktų duomenų

1 lentelè. Socialinès būsenos vertinimas ir riebios veido odos sąsajos.

Pastaba: $N$-absoliutus skaičius (respondentu skaičius); $S D$ - standartinis nuokrypis; $p$ - reikšmingито lуgтио

\begin{tabular}{|l|c|l|c|}
\hline Socialinė būsena & N & Vidurkis \pm SD & p \\
\hline Dėl savo odos vengiu bendrauti su žmonėmis & 128 & $2,09 \pm 1,08$ & $<\mathbf{0 , 0 0 1}$ \\
\hline Dẻl savo odos vengiu viešų susibūrimų & 128 & $2,12 \pm 1,23$ & $<\mathbf{0 , 0 0 1}$ \\
\hline Dėl savo odos esu linkęs(-usi) būti namuose & 128 & $1,93 \pm 1,18$ & $<\mathbf{0 , 0 0 1}$ \\
\hline $\begin{array}{l}\text { Esu i̇sitikinęs(-usi), kad mano oda trukdo man } \\
\text { susirasti partnerĭ }\end{array}$ & 128 & $1,73 \pm 1,21$ & $\mathbf{0 0 , 0 0 1}$ \\
\hline $\begin{array}{l}\text { Aš stengiuosi išvengti žmonių žvilgsnių ị } \\
\text { mano odą }\end{array}$ & 128 & $2,69 \pm 1,42$ & $<\mathbf{0 , 0 0 1}$ \\
\hline Dél savo odos atsisakau sporto & 128 & $1,25 \pm 1,02$ & $<\mathbf{0 , 0 0 1}$ \\
\hline
\end{tabular}

2 lentelè. Emocinès būsenos ir riebios veido odos sąsajos.

Pastaba: $N$-absoliutus skaičius (respondentu skaičius); $S D$ - standartinis nuokrypis; $p$ - reikšminguто lygтио

\begin{tabular}{|l|c|l|c|}
\hline Emocinė būsena & N & Vidurkis \pm SD & p \\
\hline Dèl savo odos vengiu žiūrèti ị veidrodį & 128 & $1,72 \pm 1,14$ & $<\mathbf{0 , 0 0 1}$ \\
\hline Nuolat kritikuoju save dèl odos & 128 & $2,73 \pm 1,41$ & $<\mathbf{0 , 0 0 1}$ \\
\hline $\begin{array}{l}\text { Naudoju dekoratyvinę kosmetiką tik tam, } \\
\text { kad užmaskuočiau savo odos būklę }\end{array}$ & 128 & $3,52 \pm 1,26$ & $<\mathbf{0 , 0 0 1}$ \\
\hline Man nemalonu žiūrèti ị savo odą & 128 & $2,95 \pm 1,31$ & $<\mathbf{0 , 0 0 1}$ \\
\hline Man nemalonu liesti savo odą & 128 & $2,44 \pm 1,32$ & $<\mathbf{0 , 0 0 1}$ \\
\hline Aš susirūpinęs(-usi) dèl savo odos būklès & 128 & $3,85 \pm 1,12$ & $<\mathbf{0 , 0 0 1}$ \\
\hline Mane kankina ịkyrios mintys apie mano odą & 128 & $2,73 \pm 1,53$ & $<\mathbf{0 , 0 0 1}$ \\
\hline Mano oda man kelia stresą & 128 & $2,57 \pm 1,37$ & $<\mathbf{0 , 0 0 1}$ \\
\hline
\end{tabular}

matoma, kad apklaustieji labiausiai vengia žmonių žvilgsnių ị savo odą

( $\bar{\chi}=2,69 \pm 1,42$ ), taip pat jie vengia bendrauti su kitais žmonèmis ( $\bar{\chi}=2,09 \pm 1,08$ ). Mažiausią ịtaką respondentų odos būklè turi sportui $(\bar{\chi}=1,25 \pm 1,02)$.

Analizuojant apklaustųjų emocinę būseną naudotas Kolmogorovo Smirnovo neparametrinis kriterijus (2 lentelè).

Išanalizavus gautus duomenis nustatyta, kad respondentai statistiškai patikimai ịvertino visus emocinès būsenos elementus $(\mathrm{p}<0,001)$. Iš pateiktų duomenų matoma, kad tiriamieji labiausiai jaučia susirūpinimą dẻl savo odos būklès

( $\bar{\chi}=3,85 \pm 1,12$ ), todèl daugelis iš jų naudoja dekoratyvinę kosmetiką tam, kad užmaskuotų savo

odos būklę ( $\bar{\chi}=3,52 \pm 1,26$ ). Mažiausiai respondentams įtakos turi nemalonumas liesti savo odą ( $\bar{\chi}=2,44 \pm 1,32)$, žiūrejjimas ị veidrodị ( $\bar{\chi}=$ $1,72 \pm 1,14)$.

Vertinant, kokius išgyvenimus dèl savo odos per pastarają savaitę patyrè respondentai su riebia oda, naudotas Kolmogorovo Smirnovo neparametrinis kriterijus (3 lentelè).

Išanalizavus duomenis nustatyta, kad respondentai, turintys riebią veido odą, statistiškai patikimai îvertino visus patirtus išgyvenimus per pastarają savaitę dèl savo odos $(\mathrm{p}<0,001)$. Iš pateiktų duomenų matoma, kad labiausiai jie jautèsi liūdni ( $\bar{\chi}=1,96 \pm 0,52$ ), pikti ( $\bar{\chi}=1,87 \pm 0,50$ ), uždari ( $\bar{\chi}=1,82 \pm 0,50)$, nepasitikintys savimi $(\bar{\chi}=1,80 \pm 0,62)$. Mažiausiai respondentų jautèsi nepatraukūs ( $\bar{\chi}=1,45 \pm 0,52)$.

Siekiant įvertinti jaunų žmonių, turinčių riebią veido odą, gyvenimo kokybę įvertintas respondentų pasiskirstymas pagal amžiaus grupes. Naudojant Kruskalio Voliso neparametrinị kriterijų įvertinta tiriamujų socialinè būsena pagal amžiaus grupes (4 lentelè).

Statistiškai patikimo skirtumo tarp tiriamųų amžiaus ir socialinès būsenos nenustatyta $(p>0,05)$, tai rodo, kad respondentų amžius neturèjo įtakos jų socialinei būsenai. Iš pateiktos lentelès duomenų matoma, kad visi socialinès būsenos elementai ịvertinti didžiausiais balais $18-23$ metų amžiaus jaunų žmonių grupejje. To- 
dèl, galima teigti, kad riebi veido oda turi didesnę įtaką jaunesnio amžiaus respondentų, iki 23 metų, socialiniai būsenai, lyginant su vyresnio amžiaus tiriamujų grupèmis.

Siekant nustatyti, ar yra statistiškai reikšmingų skirtumų tarp tiriamųjų amžiaus ir emocinès būsenos naudotas Kruskalio Voliso neparametrinis kriterijus (5 lentelè).

Iš gautų rezultatų matoma, kad yra statistiškai reikšmingų skirtumų tarp respondentų amžiaus grupès ir emocinès būsenos $(\mathrm{p}<0,05)$. Analizuojant duomenis nustatyta, kad $18-23$ metų amžiaus respondentai, turintys riebią veido odą, statistiškai patikimai labiau vengè žiūrèti ị veidrodị dèl savo odos $(p=0,035)$ bei buvo kankinami įkyrių minčių apie savo odą $(\mathrm{p}=0,019)$ lyginant su $24-29$ metu ir $30-35$ metų tiriamaisiais.

\section{Apibendrinimas}

Šiuo tyrimu siekta nustatyti 18 - 35 metų turinčių riebią veido odą žmonių gyvenimo kokybę. Išanalizavus gautus duomenis paaiškèjo, kad riebi veido oda sukelia estetinį diskomfortą ir turi įtakos gyvenimo kokybei.

Respondentų socialinę būseną apibūdina tai, kad dèl riebios veido odos 54,7 proc. apklaustuju vienais ar kitais atvejais vengia bendrauti su žmonėmis, 50 proc. - vengia viešų susibūrimų, 46,9 proc. yra linkę būti namuose. Magin ir kt. atliko tyrimą, kuriuo nustate, kad egzistuoja tiesioginis ryšys tarp išvaizdos ir savigarbos, žmonès, kurie jaučiasi nepatrauklūs, vengia socialinio kontakto su kitais žmonèmis [15].

Taip pat 37,5 proc. apklaustujų šiame tyrime yra ịsitikinę, kad jų oda trukdo susirasti partnerį. 2016 metais atliktas tyrimas, kuriuo nustatyta, kad iš 100 tyrime dalyvavusių pacientų, 75 proc. iš jų patiria problemų dèl artimujų ir partnerių, dèl šios problemos jautè atskirti, o dauguma moteru net manè, kad tai trukdo joms ištekèti [10].

50 proc. apklaustujų stengiasi išvengti žmonių žvilgsnių i jų odą bei 17,2 proc. respondentų dažnai dèl savo odos išvaizdos atsisako sporto. Viename iš ankščiau atliktų tyrimų tarp $11-19$ m. respondentų statistiškai reikšmingų skirtumų tarp sporto ir išvaizdos nenustatyta [17]. Tačiau kitame tyrime 68 proc. apklaustųjų pripažino, kad riebios odos problemos tiesiogiai veikia jų socialinę veiklą, jie teigè, jog jaučia, kad žmonès žiūri i jų veido odą ir jiems tai sukelia nemalonius
3 lentelè. Respondentų išgyvenimų patirtų dèl odos per pastarają savaitę duomenys.

Pastaba: $N$-absoliutus skaičius (respondentu skaičius); $S D$ - standartinis nuokrypis; $p$ - reikšmingито lygmио

\begin{tabular}{|l|c|c|c|}
\hline $\begin{array}{l}\text { Išgyvenimai per pastarąją } \\
\text { savaitę dėl savo odos }\end{array}$ & N & Vidurkis \pm SD & p \\
\hline Nepasitikėjmą savimi & 128 & $1,80 \pm 0,62$ & $<\mathbf{0 , 0 0 1}$ \\
\hline Jaučiausi uždaras(-a) & 128 & $1,82 \pm 0,50$ & $<\mathbf{0 , 0 0 1}$ \\
\hline Jaučiausi blogai & 128 & $1,61 \pm 0,51$ & $<\mathbf{0 , 0 0 1}$ \\
\hline Jaučiausi nepatrauklus(-i) & 128 & $1,45 \pm 0,52$ & $<\mathbf{0 , 0 0 1}$ \\
\hline Jaučiausi suvaržytas(-a) & 128 & $1,75 \pm 0,52$ & $<\mathbf{0 , 0 0 1}$ \\
\hline Jaučiausi liūdnas(-a) & 128 & $1,96 \pm 0,52$ & $<\mathbf{0 , 0 0 1}$ \\
\hline Jaučiausi nervingas(-a) & 128 & $1,77 \pm 0,59$ & $<\mathbf{0 , 0 0 1}$ \\
\hline Jaučiausi piktas(-a) & 128 & $1,87 \pm 0,50$ & $<\mathbf{0 , 0 0 1}$ \\
\hline Jaučiausi drovus(-i) & 128 & $1,67 \pm 0,61$ & $<\mathbf{0 , 0 0 1}$ \\
\hline
\end{tabular}

4 lentelè. Socialinès būsenos ir riebios veido odos sąsajos pagal amžiaus grupes. Pastaba: $N$-absoliutus skaičius (respondentu skaičius); $d f$-laisvès laipsnis; $p$ - reikšmingumo lygmuo

\begin{tabular}{|c|c|c|c|c|c|c|}
\hline Socialinė būsena & $\begin{array}{l}\text { Amžiaus } \\
\text { grupé }\end{array}$ & $\mathbf{N}$ & $\begin{array}{l}\text { Vidur- } \\
\text { kio ran- } \\
\text { gas }\end{array}$ & $\begin{array}{l}\text { Chi } \\
\text { kva- } \\
\text { dratas }\end{array}$ & df & $\mathbf{p}$ \\
\hline \multirow{3}{*}{$\begin{array}{l}\text { Dèl savo odos vengiu } \\
\text { bendrauti su žmonè- } \\
\text { mis }\end{array}$} & $18-23 \mathrm{~m}$. & 92 & 75,16 & \multirow{3}{*}{0,097} & \multirow{3}{*}{2} & \multirow{3}{*}{0,807} \\
\hline & $24-29 \mathrm{~m}$. & 16 & 63,64 & & & \\
\hline & $30-35 \mathrm{~m}$. & 20 & 55,78 & & & \\
\hline \multirow{3}{*}{$\begin{array}{l}\text { Dėl savo odos vengiu } \\
\text { viešų susibūrimų }\end{array}$} & $18-23 \mathrm{~m}$. & 92 & 67,24 & \multirow{3}{*}{0,487} & \multirow{3}{*}{2} & \multirow{3}{*}{0,784} \\
\hline & $24-29 \mathrm{~m}$. & 16 & 56,64 & & & \\
\hline & $30-35 \mathrm{~m}$. & 20 & 48,96 & & & \\
\hline \multirow{3}{*}{$\begin{array}{l}\text { Dèl savo odos esu } \\
\text { linkęs(-usi) būti } \\
\text { namuose }\end{array}$} & $18-23 \mathrm{~m}$. & 92 & 67,82 & \multirow{3}{*}{0,653} & \multirow{3}{*}{2} & \multirow{3}{*}{0,732} \\
\hline & $24-29 \mathrm{~m}$. & 16 & 60,25 & & & \\
\hline & $30-35 \mathrm{~m}$. & 20 & 54,76 & & & \\
\hline \multirow{3}{*}{$\begin{array}{l}\text { Esu ịsitikinęs (-usi), } \\
\text { kad mano oda trukdo } \\
\text { man susirasti partnerị }\end{array}$} & $18-23 \mathrm{~m}$. & 92 & 66,46 & \multirow{3}{*}{0,612} & \multirow{3}{*}{2} & \multirow{3}{*}{0,715} \\
\hline & $24-29 \mathrm{~m}$. & 16 & 65,90 & & & \\
\hline & $30-35 \mathrm{~m}$. & 20 & 55,50 & & & \\
\hline \multirow{3}{*}{$\begin{array}{l}\text { Aš stengiuosi išvengti } \\
\text { žmonių žvilgsnių i } \\
\text { mano odą }\end{array}$} & $18-23 \mathrm{~m}$. & 92 & 69,46 & \multirow{3}{*}{2,883} & \multirow{3}{*}{2} & \multirow{3}{*}{0,241} \\
\hline & $24-29 \mathrm{~m}$. & 16 & 52,00 & & & \\
\hline & $30-35 \mathrm{~m}$. & 20 & 55,62 & & & \\
\hline \multirow{3}{*}{$\begin{array}{l}\text { Dèl savo odos atsisa- } \\
\text { kau sporto }\end{array}$} & $18-23 \mathrm{~m}$. & 92 & 64,04 & \multirow{3}{*}{2,869} & \multirow{3}{*}{2} & \multirow{3}{*}{0,232} \\
\hline & $24-29 \mathrm{~m}$. & 16 & 54,12 & & & \\
\hline & $30-35 \mathrm{~m}$. & 20 & 61,26 & & & \\
\hline
\end{tabular}

pojūčius [10].

Respondentų emocinę būseną atspindi tai, kad 39,1 proc. vengia žiūrèti ị veidrodị, 43,7 proc. nuolat kritikuoja save dèl odos, o 51,6 proc. naudoja dekoratyvinę kosmetiką tik tam, kad užmaskuotų savo odos būklę. $2017 \mathrm{~m}$. buvo atliktas tyrimas, kurio metu buvo analizuojama ị aknę linkusios odos turinčių žmonių gyvenimo kokybė. Tyrime 
5 lentelè. Emocinès būsenos ir riebios odos sąsajos pagal amžiaus grupes. Pastaba: $N$-absoliutus skaičius (respondentu skaičius); $d f$ - laisvés laipsnis; $p$ - reikšmingumo lygmuo

\begin{tabular}{|c|c|c|c|c|c|c|}
\hline Emocinė būsena & $\begin{array}{l}\text { Amžiaus } \\
\text { grupé }\end{array}$ & $\mathbf{N}$ & $\begin{array}{l}\text { Vidurkio } \\
\text { rangas }\end{array}$ & $\begin{array}{l}\text { Chi } \\
\text { k v a - } \\
\text { dratas }\end{array}$ & df & p \\
\hline \multirow{3}{*}{$\begin{array}{l}\text { Dèl savo odos vengiu } \\
\text { žiūrèti ị veidrodị }\end{array}$} & $18-23 \mathrm{~m}$. & 92 & 72,24 & \multirow{3}{*}{6,112} & \multirow{3}{*}{2} & \multirow{3}{*}{0,035} \\
\hline & $24-29 \mathrm{~m}$. & 16 & 46,50 & & & \\
\hline & $30-35 \mathrm{~m}$. & 20 & 52,26 & & & \\
\hline \multirow{3}{*}{$\begin{array}{l}\text { Nuolat kritikuoju save } \\
\text { dèl odos }\end{array}$} & $18-23 \mathrm{~m}$. & 92 & 68,04 & \multirow{3}{*}{2,556} & \multirow{3}{*}{2} & \multirow{3}{*}{0,197} \\
\hline & $24-29 \mathrm{~m}$. & 16 & 66,12 & & & \\
\hline & $30-35 \mathrm{~m}$. & 20 & 26,02 & & & \\
\hline \multirow{3}{*}{$\begin{array}{l}\text { Naudoju dekoratyvinę } \\
\text { kosmetiką tik tam, kad } \\
\text { užmaskuočiau savo odos } \\
\text { būklę }\end{array}$} & $18-23 \mathrm{~m}$. & 92 & 68,64 & \multirow{3}{*}{3,173} & \multirow{3}{*}{2} & \multirow{3}{*}{0,219} \\
\hline & $24-29 \mathrm{~m}$. & 16 & 46,30 & & & \\
\hline & $30-35 \mathrm{~m}$. & 20 & 67,52 & & & \\
\hline \multirow{3}{*}{$\begin{array}{l}\text { Man nemalonu žiūrèti ị } \\
\text { savo odą }\end{array}$} & $18-23 \mathrm{~m}$. & 92 & 69,72 & \multirow{3}{*}{2,870} & \multirow{3}{*}{2} & \multirow{3}{*}{0,188} \\
\hline & $24-29 \mathrm{~m}$. & 16 & 51,13 & & & \\
\hline & $30-35 \mathrm{~m}$. & 20 & 54,29 & & & \\
\hline \multirow{3}{*}{$\begin{array}{l}\text { Man nemalonu liesti } \\
\text { savo odą }\end{array}$} & $18-23 \mathrm{~m}$. & 92 & 68,92 & \multirow{3}{*}{2,061} & \multirow{3}{*}{2} & \multirow{3}{*}{0,384} \\
\hline & $24-29 \mathrm{~m}$. & 16 & 57,61 & & & \\
\hline & $30-35 \mathrm{~m}$. & 20 & 51,74 & & & \\
\hline \multirow{3}{*}{$\begin{array}{l}\text { Aš susirūpinęs(-usi) dèl } \\
\text { savo odos būklès }\end{array}$} & $18-23 \mathrm{~m}$. & 92 & 70,11 & \multirow{3}{*}{3,330} & \multirow{3}{*}{2} & \multirow{3}{*}{0,237} \\
\hline & $24-29 \mathrm{~m}$. & 16 & 53,12 & & & \\
\hline & $30-35 \mathrm{~m}$. & 20 & 50,74 & & & \\
\hline \multirow{3}{*}{$\begin{array}{l}\text { Mane kankina įkyrios } \\
\text { mintys apie mano odą }\end{array}$} & $18-23 \mathrm{~m}$. & 92 & 72,27 & \multirow{3}{*}{7,462} & \multirow{3}{*}{2} & \multirow{3}{*}{0,019} \\
\hline & $24-29 \mathrm{~m}$. & 16 & 50,51 & & & \\
\hline & $30-35 \mathrm{~m}$. & 20 & 49,62 & & & \\
\hline \multirow{3}{*}{$\begin{array}{l}\text { Mano oda man kelia } \\
\text { stresą }\end{array}$} & $18-23 \mathrm{~m}$. & 92 & 70,39 & \multirow{3}{*}{5,065} & \multirow{3}{*}{2} & \multirow{3}{*}{0,067} \\
\hline & $24-29 \mathrm{~m}$. & 16 & 61,15 & & & \\
\hline & $30-35 \mathrm{~m}$. & 20 & 39,06 & & & \\
\hline
\end{tabular}

dalyvavo 110 žmonių, kurių amžiaus vidurkis 26 m. $( \pm 6,6)$, tačiau didžiają dalị sudare studentai. Šiuo tyrimu išsiaiškinta, kad jaunų moterų jaudinimasis dèl šios problemos poveikio išvaizdai yra gerokai didesnis nei vyrų [12].

Vertinant respondentų atsakymus, nustatyta, kad 36 proc. nemalonu žiūrèti ị savo odą, 40,6 proc. nemalonu ją liesti, 65,7 proc. yra susirūpinę dèl savo odos būklès, 53,2 proc. kankina įkyrios mintys apie jų odą bei 46,9 proc. pasisakè, kad oda jiems kelia stresą.Riebi veido oda 31,3 proc. kelia nepasitikejjmą savimi, 23,4 proc. jaučiasi dèl to blogai, 39,1 proc. jaučiasi uždari, 57,8 proc. - nepatrauklūs, 32,8 proc. - suvaržyti, 21,9 proc. - liūdni, 31,3 proc. - nervingi, 23,3 proc. - pikti bei 39,1 proc. yra drovūs. 2013 metais atliktame tyrime paaiškejjo, kad žmonès, turintys riebią veido odą ir joje išreikštus bėrimus, turi psichologinių sunkumų, jie jaučia nerimą, depresiją, priešiškumą ir baimę [2]. Remiantis Irane atlikto panašaus tyrimo duomenimis, nustatyta, kad 68,3 proc. apklaus- tụjų jautė nerimą dèl savo odos būklès [9].

Vertinant respondentus pagal amžiaus grupes nustatyta, kad riebi veido oda socialinei būsenai turi didesnę įtaką jaunesnio amžiaus respondentams nuo 18 iki 23 metų, lyginant su vyresnio amžiaus tiriamaisiais. Taip pat šios amžiaus grupès tiriamieji dèl savo odos labiau vengia žiūrèti ị veidrodị bei yra nuolat kankinami įkyrių minčių apie savo odą. Tačiau $24-29$ metų amžiaus grupès respondentai dèl savo odos jaučiasi labiau nepatrauklūs, suvaržyti bei drovesni.

Vertinant streso įtaką odos ligoms ir problemoms pastebeta, kad stresas tiesiogiai veikia odos būklę, šioje situacijoje susidaro užburtas ratas - žmogus jaučia stresą dèl savo odos, todèl ši būklè ne gerèja, o blogèja [6]. Tyrimai rodo, kad sumažinus streso lygị asmenų, turinčių estetinių odos problemų, odos būklè pagerèja [6].

\section{Išvados}

1. Atliktas tyrimas parodè, kad riebi veido oda sukelia psichologini diskomfortą ir turi įtakos jaunų žmonių gyvenimo kokybei $(\mathrm{p}<0,05)$. Riebi veido oda blogina ją turinčių žmonių socialinę ir emocinę būseną.

2. Nustatyta, kad riebi veido oda turi didesnę itaką gyvenimo kokybei tarp 18 - 23 metų nei $24-35$ metų amžiaus žmonių.Tačiau statistiškai reikšmingo skirtumo tarp tiriamujų amžiaus ir socialinès būsenos nèra $(\mathrm{p}>0,05)$.

3. Dèl riebios veido odos patiriamo diskomforto pablogèja jaunų žmonių emocinè būsena $(p<0,05) .18-23$ metų respondentai labiau vengia žiūrèti ị veidrodị bei yra nuolat kankinami ikyrių minčių apie savo odą ( $<<0,05) .24-29$ metų respondentai dèl riebios veido odos jaučiasi labiau nepatrauklūs, suvaržyti bei drovūs $(p<0,05)$.

\section{Literatūra}

1. Apfelbacher CJ., Ofenloch RF. The impact of skin conditions on generic health-related quality of life. British Journal of Dermatology 2017; 176:1109-1110.

https://doi.org/10.1111/bjd.15453

2. Behnam B, Taheri R, Ghorbani R, Allameh P. Psychological impairments in the patients with acne. Indian Journal of Dermatology 2013; 58(1):26.

https://doi.org/10.4103/0019-5154.105281 
3. Bundy C. Is education enough to improve quality of life in people with chronic inflammatory skin conditions? British Journal of Dermatology 2016; 174:1179-1193.

https://doi.org/10.1111/bjd.14611

4. Dawson AL, Dellavalle RP. Acne vulgaris. Bmj 2013; 346, f2634.

https://doi.org/10.1136/bmj.f2634

5. DąbrowskaAK, Spano F, Derler S, Adlhart C, Spencer ND, Rossi RM. The relationship between skin function, barrier properties, and body-dependent factors. Skin Res Technol 2017; $1-10$.

6. Dixon LJ, Wicraft SM, Mc Cowan NK, Brodell RT. Stress and skin disease quality of life: the moderating role of anxiety sensitivity social concerns. British Journal of Dermatology 2017; 178 (4):951-957.

https://doi.org/10.1111/bjd.16082

7. Dou J, Guo X, Yao Y, Zhang Y. Analysis on reliability and validity of adaptation OSSIQ in measuring life quality of populatios with different types of subjective skin. Journal of Jilin University (Medicine Edition) 2017; 43(2):435-440.

8. Gancevičienė R., Lukavičiūtè L., Navickas P., Navickas A. Grigaitienè J., Zouboulis CC. Aknès ịtaka emociniams sutrikimams. Sveikatos mokslai, 2018;28(3):30-35.

9. Golchai J, Khani SH, Heidarzadeh A, Eshkevari SS, Alizade N, Eftekhari H. Comparison of anxiety and depression in patients with acne vulgaris and healthy individuals. Indian Journal of Dermatology 2010; 55:352-4.

https://doi.org/10.4103/0019-5154.74539

10. Hazarika N, Archana M. The psychosocial impact of acne vulgaris. Indian Journal of Dermatology 2016; 61(5):515. https://doi.org/10.4103/0019-5154.190102

11. Kozlowska J, Kaczmarkiewicz A, Stachowiak N, Sionkowska A. Evaluation of sebostatic activity of juniperus communis fruit oil and pelargonium graveolens oil compared to niacinamide. Cosmetics 2017; 4:36.

https://doi.org/10.3390/cosmetics4030036

12. Kulthanan K, Jiamton S, Kittisarapong R. Dermatology life quality index in Thai patients with acne. Siriraj Medical Journal 2017; 59(1):3-7.

13. Langenbruch A, Radtke MA, Gutknecht M, Augustin M. Does the dermatology life quality index (DLQI) under stimate the disease-specific burden of psoriasis patients? Journal of the European Academy of Dermatology and Venereology 2019; 33:123-127.

https://doi.org/10.1111/jdv.15226

14. Lideikaitė A., Malevič A., Gancevičienė R. Pacientų, sergančių akne, gyvenimo kokybės vertinimas. Sveikatos mokslai, 2018; 28(1): 5-9.

https://doi.org/10.5200/sm-hs.2018.001

15. Magin P, Adams J, Heading G, Pond D, Smith W. Psychological sequelae of acne vulgaris: Results of a qualitative study. Can Fam Physician 2006; 52:978-9.
16. Pärna E, Aluoja A, Kingo K. Quality of life and emotional state in chronic skin disease. Acta Derm Venereol 2015; 95: 312-316.

https://doi.org/10.2340/00015555-1920

17. Tasoula E, Gregoriou S, Chalikias J, Lazarou D, Danopoulou I, Katsambas A, Rigopoulos D. The impact of acne vulgaris on quality of life and psychic health in young adolescents in Greece: results of a population survey. Anais Brasileiros de Dermatologia 2012; 87(6):862-869.

https://doi.org/10.1590/S0365-05962012000600007

\section{COHERENCE OF YOUNG PEOPLE QUALITY OF LIFE AND OILY SKIN}

G.Šniepienė, J.Gudaitytè, S.Urbonienè

Key words: quality of life, oily skin, sebum.

Summary

Background. Oily skin is characterized as large a pair of facials, shiny appearance, and a feeling of greasiness and heaviness. This type of skin often causes aesthetic problems but it can also be a source common skin disorders such as acne vulgaris and seborrhoeic dermatitis. This can often lead to negative self-perception, low self-esteem, depression and fear due to excessive sebum production $[5,12]$.

Research aim. To analyse coherence of young people quality of life and oily skin.

Research subject. Coherence of quality of life and oily skin.

Research methods. The original questionnaire based on scientific information sources was applied. Questioned 396 respondents aged from 18 to 35 years, 128 from them with oily facial skin. The data analysis was subject to the software package IMB SPSS Statistics (version 19). Used data analyzed: the Shapiro-Wilk criterion (was used for the data analysis), the Kolmogorov-Smirnov's nonparametric criterion (was used for one group of respondents) and the Kruskal-Wallis criterion (was used for more than two groups of respondents). The data were coded, the values were standardized, and the mean values, standard variations, median, frequencies, percentage, and statistical significance were calculated.

Outcoms. Young people's social and emotional life is more limited because of oily facial skin. They avoid communications, avoid public gatherings and because of their skin they are left at home. People who have the oily skin constantly feel stress and the other negative feelings. In assessing the respondents by age groups it was ascertained that the oily facial skin has more influence on younger respondents from 18 to 23 years and has a greater impact on their social and emotional state than elderly groups of investigators. Also this age group statistically significantly avoids looking at themselves in the mirror $(p<0,05)$, as well as are obsessed by intrusive thoughts about their skin $(\mathrm{p}<0,05)$ more than aged from 24 to 35 years respondents. However, the respondents aged from 24 to 29 years feel more unattractive $(\mathrm{p}<0,05)$, constrained $(p<0,05)$ and more shy $(p<0,05)$ because of their oily facial skin.

Conclusions. The research revealed that oily facial skin causes the psychological discomfort and has influence on the quality of young people lifes. It was determined that the oily facial skin worsens the social and emotional state of people with oily facial skin.

Correspondence to: g.sniepiene@kvk.lt

Gauta 2019-03-12 